\title{
Dobrosław Mańkowski*
}

iD https://orcid.org/0000-0001-5113-0743

\section{SPORT IN THE TIME OF TRANSFORMATION IN POLAND. GDAŃSK CASE STUDY}

\begin{abstract}
Various areas of social and economic life and their changes during the political transformation after 1989 have been studied and analyzed by Polish sociologists. It seems that one of the areas that has been left out and which constitutes a terra incognita is the world of sport.

As in other areas, individual and collective social actors who organized, managed or participated in the world of sport had to come to terms with the new social, economic and political order. That is why the transformation seen through their eyes and what they did, their motivations and ways of coping with changes are interesting and broaden our knowledge about the transformation period.

In the article, I present a fragment of my own research on the course and effects of political transformation, based on the example of a multi-sectional Workers' Sports Club Stoczniowiec Gdańsk (currently GKS Stoczniowiec Gdańsk). I was interested in the struggles of people who organized sport, which they had to face in the period of transformation. I was interested in how they experienced the clash with the emerging new social order. What strategies they adopted in their organizational activities and their practices during the transformation. The case study is treated as a field study and a conceptual pilot study which is a starting point for further exploration. I used two methods: desk research (among others, press articles, club information, official data, statistical data were collected) and in-depth interviews (IDI) with social actors operating in the sports club. The analytical framework for the study consists of three dimensions of transformation, namely the economic, political and legal, and social ones. The theoretical foundations, on the other hand, are the perspectives of new institutionalism, especially the theory of fields by Fligstein and McAdam and the concept of deinstitutionalization by Christine Oliver.
\end{abstract}

Keywords: sociology of sport, sports club, transformation, social change, sociology of transformation.

\section{Introduction}

In this article, I want to present a portion of a larger study I am conducting on sports clubs in the time of transformation in Poland. The aim of the study is to show models that explain the opportunities of sports organizations and the trajectories

* MA, Institute of Sociology, University of Gdańsk, ul. Bażyńskiego 4, 80-309 Gdańsk, e-mail: dobroslaw.mankowski@ug.edu.pl 
of their operation in the period of socio-economic and political transformation in Poland since 1989. What is essential for the research are the strategies of action of social actors in the institutional field of sport, including their activities in sports organizations as such. I am particularly interested in the struggles of people organizing sport in a new social and economic situation. I ask about how they experienced a clash with the emerging new social order; what strategies they adopted in what they did during the transformation (Giza-Poleszczuk et al. 2000); what form the evolution of the institutional field of sport took, and, importantly, what practices they implemented in a sports club to continue its sports activities.

Hence, I have formulated the following research questions: What changes occurred in the sports club during the transformation? What factors (social, political, economic) caused the deinstitutionalization or reinstitutionalization of the sports club? What was the role of social actors in the processes of restructuring of the sports club? What was the role of the state and/or local government in the processes of changes taking place in the club? What was the role of the pre-transformation club environment (sponsor companies) in the processes of changes? What was the impact of the club's social and material resources on its fate?

For the purposes of this article I have conducted a case study of the Workers' Sports Club (RKS) Stoczniowiec Gdańsk (later Gdańsk Sports Club Stoczniowiec Gdańsk) based in Gdańsk. In 1989 the club had ten sports sections: ice hockey, figure skating, weightlifting, volleyball, boxing, rowing, canoeing, football, sports bridge and karate. In Communist times, from its establishment in 1970, the club was managed by the Union of the Shipbuilding Industry and its resources included the "Olivia" sports hall, a football stadium and two smaller sports halls. The chosen sports club is one of the types of the sports organizations which have had to struggled in the new order that emerged in the time of economic and political transformation. My choice was based on the club's belonging to the industrial sector of the state.

This article is divided into parts. In the first part I describe the context of socio-economic and political transformation in Poland. The next part explains the theoretical background of my research. The third part concerns methodology. In the fourth part I presents my research findings. This part is also divided into sections to show better relations between sport clubs and other organizations or the state in the time of transformation. The last part contains the conclusions.

\section{Socio-economic and political transformation in Poland}

It has been more than 30 years since the fall of communism in Poland. In 1989 Polish society faced a new challenge: the introduction of democracy and the free market economy (Marody et al. 2019). The transformation of the political system was a holistic social change, and so it entailed the introduction of 
a new social order (Krzemiński 2011; Marody 2011). This change consisted in transforming the socialist (communist) system into a democratic and capitalist one (Giza-Poleszczuk et al. 2000). The new order was built "not so much on the ruins of the communist system, but rather from these ruins" (Marody 2011: 67). Hence, when studying the transformation one should take into account the acquired social habits that were created in communist times, their impact on the time of change, and also the current social situation in Poland (Marody 2011; Marody et al. 2019).

Economic changes were implemented in accordance with the neoliberal creed. The government chose the road TINA (There Is No Alternative), whose author was Leszek Balcerowicz. TINA consisted in freeing the market and creating conditions in which there was the least possible state interference in the market (Kowalik 2012). Moreover, no social costs were taken into account on this path. It was recognized that they must occur. The free market was the most important thing for the reformers. Increasing unemployment, inflation, and fiscalism implemented step by step negatively affected many areas of social life. In addition, the accelerated and not very well-regulated privatization of the industrial sector led to the collapse of Polish industry in its entirety (Karpiński et al. 2013; 2015). This also led to many different social problems. It also intensified pathologies, the enrichment of state assets, and quickly achieved fortunes as well as fast bankruptcies. In the first period of the transformation, the economy was not stable, which meant that the entire society was subjected to various types of shocks.

Changes in economics were also visible in the field of politics. The first years of the transformation were unstable, full of shocks and changes in the government. The government based on the "Solidarity" social movement was unable to develop a strategy for stable governance. Post-communists came to power after winning the election in 1993. The Democratic Left Alliance (Sojusz Lewicy Demokratycznej, hereafter SLD) continued with the reforms, leading to the consolidation of the free market. It implemented reforms in the area of social and labour policy. In the context of the field of sport, state policy did not change much. A new law on physical culture was still lacking. This act was adopted in 1996. In 1997, Solidarity Electoral Action (Akcja Wyborcza Solidarność) won the election. They carried out reforms regarding public administration, education and health. Also they supported reforms that liberalized the labour code and weakened the pension scheme (Rek-Woźniak, Woźniak 2017). In 1997 the country began to stabilize, but the cost of reforms led to SLD coming to power again. In the following years government directed by SLD stabilized the economy and various types of institutions. This allowed Poland to join the European Union in 2004. This moment is considered to be the end of the transformation in Poland (Drozdowski 2009; 2014; Gronkiewicz-Waltz 2004; Kowalik 2012; Ziółkowski 2014; Marody et al. 2019).

Sociologists have studied social and political transformation in numerous social fields and dimensions: the primacy of endogenous forces, capitalism, elite 
leadership, lack of unity (McSweeney, Tempest 1993), institutional change (Morawski 1998a; Federowicz 2004), political elites, politics (Staniszkis 2001; Kowalik 2012), changes in the economy - including: industry structure, unemployment, work, wages, poverty, etc. (Dunn 2017; Karpiński et a1. 2013; 2015; Bałtowski, Miszewski 2015; Rek-Woźniak, Woźniak 2017; Leyk, Wawrzyniak 2020), as well as attempts at a holistic approach to society and transformation (Giza-Poleszczuk et al. 2000; Chołaj 1998; GronkiewiczWaltz 2004; Krzemiński 2011; Marody et al. 2019). Currently, sociological reflection on the events that took place after the collapse of communism is linked to historical sociology (Gadowska, Rymsza 2017; Kolasa-Nowak 2015). Despite significant achievements in research work, there are gaps in the sociology of transformations. One of such social areas, which is a kind of terra incognita in research of sociology of transformations, is sport.

\section{Theoretical backgrounds}

In my study, I employ two theoretical concepts that allow for better visualization and understanding of the change processes taking place in organizations. The first concept is Neil Fligstein and Doug McAdam's theory of fields (2012). The other is related to deinstitutionalization processes, as proposed by Christine Oliver (1992). Both theoretical concepts are derived from the perspective of new institutionalism, i.e. a perspective that seeks to holistically embrace the actions of social actors in institutional fields. It is worth emphasizing that in the sociology of transformations social change processes are indicated as processes of institutional change, where four types of processes can be distinguished: institutionalization, reinstitutionalization, deinstitutionalization and creating new institutions (Morawski 1998b; Federowicz 2004).

The theory of fields refers to "how local orders are created, sustained and transformed" (Fligstein 2009: 279). A local order is understood as a structure within a field (Mańkow ski 2018). An organization creates a strategic action field (institutional field), where there is a structure and social actors operating in their positions. These positions include incumbents and challengers, where incumbents are social actors with power, and challengers are in opposition (actors jockeying for power). As has been mentioned, no changes or social activities take place in a social vacuum. Hence, strategic action fields are embedded in an environment, in which they form a network of interconnections and interdependencies. A sports club, which here is treated as a strategic action field, conducts its activities in a given environment (sports system) and is related to other institutional fields (organizations). The relationship between organizations is stronger or weaker and results from the impact of one organization on another organization. As I will present later, these relationships will have a significant impact on the fate of the 
club and the activities of social actors representing and having power in the club. Further on in the text, I will address the proposals of Fligstein and McAdam in more detail, also in connection with their strong emphasis on institutional changes within the field, as well as the attention given to the activities of social actors (and their empowerment).

Christine Oliver's concept of deinstitutionalization processes originated directly from the lack of attention of paid by the representatives institutionalism to such processes (Oliver 1992; Dacin, Dacin 2008). The potential of the concept of deinstitutionalization to a considerable extent calls into question the stability and longevity of an institution, suggesting that under specific conditions institutionalized practices and values change, and that due to change they may be rejected (Oliver 1992), which may lead to institutional (organizational) erosion. "Deinstitutionalization is defined here as the process by which the legitimacy of an established or institutionalized organizational practice erodes or discontinues" (Oliver 1992: 564). Institutional organizational practice refers to the activities of actors performed within the organization, and to their activities in the external field performed on behalf of the organization. The de-legitimation of this practice or organizational procedures results from the challenges faced by an organization (institution), or its failure to reproduce previously legitimated and taken-for-granted organizational actions. The proposed concept of deinstitutionalization seeks to highlight that in specific circumstances action and change within the organization/ institution does not result from the consensus adopted by the group or sharing common values, but rather from rejecting them, and thus from the failure to reproduce the existing rules and norms. It also seeks to explain changes taking place in the organization, the rejection of fixed behaviours and habits, and to explain the reasons for the external, permanent institutional pressures on an organization leading to its deinstitutionalization (Oliver 1992). The researcher identifies three main factors predicting deinstitutionalization. These include political, functional and social factors. Political factors occur when the legitimacy of practice is questioned. This applies to conditions in which crises occur: performance, the representation of organization members, a common status quo or the impossibility of introducing innovation. There is a discrepancy between procedural conformity and expectations (Dacin, Dacin 2008). Functional factors occur when there is a redistribution of power and when changes to the perceived utility and/or technical instrumentality of the practice pursued so far take place. Social pressures accelerate deinstitutionalisation, because they cause the organization to cease being proactively involved in activity. This is due to the fact that there is normative fragmentation, the workforce increases or decreases, there is a merger with other organizations, or there are changes in the law or social norms that do not consolidate institutional practice in any way. Collectively perceived norms and values erode (Oliver 1992).

Studying deinstitutionalization processes is important in the context of changes taking place in sport during periods of transformation. The statistical data 
collected by the Central Statistical Office shows a drastic decrease in the number of sports organizations and the number of people practising sport in Poland after 1989. In 1988 there were over 33,000 sports organizations. In 1991 there was a drop to 13,000 organizations, then reaching the number of only 11,000 in 1993. Hence, the question about the collapse of sports organizations in the period of social change becomes relevant.

\section{Methodology}

Amy Bass (2014) suggests describing sport and its dimensions in its "messy" and unique complexities. Despite its great impact on society, sport is underestimated by both historians and sociologists (Bass 2014; Jakubowska, Nosal 2017). The impact of sport on society can be measured in economic and social terms, but also in emotional terms (emotions evoked in sport fans). In addition, one may notice problems arising from defining sport and its essence (see Stempień 2020). Hence, writing about sport is not easy. Following what Bass proposed, I think that sociological reflection on sport during the transformation period should address complexities: from stories of witnesses through press articles, information found on the Internet, official documents and photos, to stories told as anecdotes. Such a holistic view allows for building a picture of the activities of individuals and social groups, their motives, achievements and failures, and the practices they used to survive in the time of great change. That is why I use a case study strategy that "requires an in-depth and comprehensive analysis of a specific case, together with the context of its functioning" (Strumińska-Kutra, Koładkiewicz 2012: 2).

In a case study, the data is collected from a number of sources, and with the triangulation method data consistency is confirmed, "while in the process of data collection and analysis a reference is made to the pre-formulated theoretical assumptions" (Yin 2015: 49). What is more, case study research can be exploratory. It is essential in the context of my study because so far no studies have been conducted on the opportunities of sports clubs during the transformation. The effect of an exploratory case study is the definition of general questions and hypotheses for future research (introduction to the research proper) (Strumińska-Kutra, Koładkiewicz 2012). Robert K. Yin (2015) refers to such a study as an innovative case study. The subject matter of a case study are activities, practices and phenomena that have not been subject to analysis so far. My research is situated as an exploratory/innovative case study.

I have obtained data from various sources. I made use of desk research - in particular based on:

1) press articles published in the "Dziennik Bałtycki" daily in the years 1989-2004. It was the only newspaper that survived the transformation period, was continuously published and dealt with local affairs and events; 
also it is the largest daily in Gdańsk and Pomerania. I have to add that during the query, I selected 1886 press articles that referred to any extent the research issues of the project. Over 100 articles concerned the Stoczniowiec sports club and its relationship to the field of sport;

2) official documents (such as, e.g., transcripts of the sports committee, resolutions regarding sport in Gdańsk, legal acts, etc.);

3) I used the data available on the Internet.

In the period between November 2019 and March 2020 I conducted ten individual in-depth interviews (IDI) with people managing the sports club and I conducted expert interviews with journalists dealing with sport in Gdańsk and Pomerania in the transformation period (Bogner et al. 2009; Muskat et al. 2012).

The results of the case study data analysis are presented below.

\section{Research findings}

In May 1989, a journalist Paweł Kowalski writes about RKS Stoczniowiec:

It flourished, being one of the top national leaders, when it was generously supported by the Union of the Shipbuilding Industry and sponsor companies. It lost its stability when the Polish economy collapsed. Today, like many sport clubs, it is going through a deep crisis, it has debts ${ }^{1}$ (Kowalski 1989).

And it will stay like that. The story of sport under transformation is not a story about achievements or triumphs, but about the efforts taken when facing a fall, debts, bankruptcy and the difficulties of everyday life. The stories carry the burden of the world that came after 1989, which is the world of transition, change and uncertainty. The battlefield where you struggle for another day. One of the participants of this struggle puts it aptly:

Earlier, the club, the Olivia hall, were $100 \%$ financed by the committee, as if by the state - there was money for coaches and hall maintenance, there was some symbiosis. And all of a sudden the funding stopped - I compare it to the situation where, all schools in Poland are no longer financed - this is the same model, i.e. we have an arrangement, because there are some private schools and the state makes an arrangement, because it stops financing education - and further - it was a shock, nobody knew nothing about the free market economy, nobody had done it before, inflation was rampant and the club was getting deeper and deeper into problems (interview 1).

That being so, how to find your place in such a situation? Did social actors use a typical organizational response to a novelty, i.e. finding routine actions that could be applied in such a situation (March, Olsen 2005)? Or maybe they were looking for new solutions? Something unconventional, new, unknown, just like the

${ }^{1}$ All quotations from "Dziennik Bałtycki" are marked with the footnote: author's name, year, and details are provided in the references. 
whole social reality which they were in? Searching for answers to these questions is not easy. The whole of society found itself in a situation where neither the authors of the reforms "nor the »recipients" had full knowledge about what difficulties and obstacles they would encounter during their implementation or what the social costs of the potential success of this undertaking would be" (Goszczyńska 2010: 17). Sports activists did not know what to do either. They do not know of any models for reaction to such socio-economic change. It has to be noted that the previous situation was perfect for sports organizing entities. There were no problems with seeking sources of funding, with acquiring sports equipment or securing sports infrastructure. Everything was arranged, structured and financed by the socialist state. Maybe it wasn't big money, counted in millions, but it was real, it did not put sports clubs into debt and, crucially, it ensured remuneration for the athletes.

\section{Apocalypse now}

In the case of RKS Stoczniowiec, the years 1989-1993 were simply the last days. All entities cut themselves off from the club and there was no dialogue with the state authorities, which led the club to a gigantic debt. David Graeber notes that the basic problem with debts is the assumption that "one has to pay their debts" (2017: 9). This assumption neither disappeared nor was left aside at the time of transformation. Debt was an inseparable part of the time of transformations and applied equally to enterprises, citizens and sports clubs. No one cared about the variety of reasons behind the debts, or the particular situation where public entities were indebted to public institutions due to the cost of transformations. While politicians struggled to reduce the national debt towards foreign creditors, the debts existing inside the country between various types of institutions, organizations or social actors (individual and collective) remained debts which had to be paid. Nobody would consider their reduction. Regardless of the time, debt always "becomes the horizon and the reference point for uncertain decisions" (Lewicki 2019: 17). We should look at the operation of sports clubs from this perspective. My research shows that debt was, is and will be a part of the operation of sports clubs in the era of capitalism.

In 1993, in an interview for "Dziennik Bałtycki" the new chairman of Stoczniowiec says: "I took over a club with 8 sections and a basic debt of over 3 billion (5.5 billion with interest ${ }^{2}$ )" (Suska 1993). The accrued liabilities were payments for the personnel of the club and the facility, payments to the Social Insurance Institution plus payments for electricity and heating providers. Until 1 January

2 The amounts are the amounts before the denomination that took place in 1994. The denomination consisted of cutting off four zeros: PLN 1,000,000,000 = PLN 100,000 (one billion = one hundred thousand). 
1990 these payments had laid within the responsibility of the sponsoring industrial plant. At the same time, the club received money from voivodship physical culture committees, for example for athletic scholarships. One of the interviewees describes the change of situation:

However, the situation started to look tragic - from 1 January 1990, when the then minister of sport, and actually the government, the physical culture committee and the sports committee, all committees of physical culture and sports in all voivodeships stopped financing the clubs (interview 1).

Debts would accrue because there was no income. There were only costs. Financing by shipbuilding plants had come to an end. Interestingly, the personnel of the plants did not stop using the Olivia sports hall. This is noticed by an interviewee: "It was a bizarre situation - shipyard workers used the gym, everything, free of charge, we tolerated it, while the Northern Shipyard, our guardian, did not feel any financial obligation" (interview 1). We should remember that until the end of 1989 all senior club players collected remuneration in the Northern Shipyard. Another interviewee recalls:

I never signed any document that stated I was employed. I don't know, they told me to go to the Shipyard, I went there, collected the money, signed confirmation of receipt, but I never signed any document stating that I was employed in the Shipyard, or I absolutely never signed a contract in Stoczniowiec (interview 3).

Before the transformation, such procedures can be described as symbiosis. The Northern Shipyard paid for the players and club facilities, and its employees used the facilities free of charge. In the new reality, the situation was completely different. As already mentioned, shipyard employees still used club facilities free of charge, while the shipyard did not support the club in any way. In the free market circumstances, this situation led the club to bankruptcy.

\section{Industrial collapse to mark the end of sport?}

The relation between sport and industry ${ }^{3}$ has left its mark on the processes leading to the collapse of sports organizations. Stoczniowiec, connected with the Union of the Shipbuilding Industry, was not an isolated case of where the collapse of enterprises led to the problems of the sports club. To give an example, in Gdańsk, BKS Lechia Gdańsk, sponsored by the Union of the Building Industry, had problems. The relation between sport and ministries from Communist times

${ }^{3}$ Also fascinating are the relations between sports clubs and other departments such as defense ministers or home affairs to which these clubs were subject. However, this is an area of research that is beyond the scope of this paper, because I am analyzing the case of an industrial club; I will describe other ones elsewhere. 
was destructive during the transformation. The industry was collapsing under the introduction of deep privatization. As noted by Bałtowski and Miszewski (2015: 100-101): "Privatization or, more broadly, de-etatization of the sector of state-owned enterprises is a necessary element of transformational changes". The activities taken in this respect were based on the assumption that

since the state wastes its material resources (which is difficult not to agree with), then the transformation alone of these resources into private resources will increase efficiency on a microscale and re-orient enterprises to financial benefits, which will result in increased efficiency on a macro-scale. Reality did not fully confirm such an assumption (Bałtowski, Miszewski 2015: 102).

An important element is the de-etatization mentioned by the authors, which had already begun in Gdańsk in the 1980s. This was due to the Independent and SelfGoverning Trade Union (NSZZ) "Solidarność" which started to take the floor in industrial plants. Especially in Gdańsk and in the shipbuilding industry, people linked to trade unions started to have influence on the company's economic policy. Intent on cost-cutting, they started by cutting back on the "empty posts" of athletes. Shipyard managers did not negate the moves imposed by the trade unions. As an interviewee notes: "Each management, whether the Communist one and later some of those decision-makers [from Solidarity - author's note] - in my opinion sport was over on the Coast in 1981, as a punishment for those strikes" (interview 2). As the "punishment" for strikes in cooperation with those who initiated them, the authorities cut off the clubs in Gdańsk from financing before 1989. This was in contrast to the clubs from Upper Silesia, which did not experience such changes, as recalled by one of the interviewees:

Anyway, all sections based on the shipbuilding industry or the Gdańsk Shipyard and their cooperating parties - from that time on everything was a punishment, and while the mining industry, etc., received strong financing, here the regression was clear and, despite numerous players, it collapsed (interview 2).

This situation was not favourable for sports clubs after 1989. Deindustrialization, de-etatization and the privatization of state-owned industrial enterprises were external processes that affected sports clubs.

It should be mentioned that the research on deindustrialisation includes criticism of the processes leading to the collapse of existing industrial enterprises. Such large-scale collapse is not identical to the "so-called normal, natural deindustrialization, which is currently observed in a number of Western countries, but is closer to the pathological form of deindustrialization" (Karpiński et al. 2015: 33-34). Industrial collapse was the result of the shock therapy. Similarly, in the sports industry no procedures of adapting to the new conditions were introduced. In other words, no transition rules existed. The state policy towards industry was based on liberal solutions and the assumption of the need to impose these solutions on Polish society, which was resistant to them and not enlightened enough 
(Bałtowski, Miszewski 2015; Kowalik 1992). At the same time, fiscalism and the opening of foreign trade contributed to the collapse of industry, which entailed social costs: unemployment and poverty - as well as the lowest social strata going into debt. This led directly to social stratification at the moment when a "transformational class" was emerging on the other side. The "transformational class" is a narrow group of people who benefit from low-quality law, an open economy, poor state control, special conditions based on speculation and access to decision-making centers (Staniszkis 1994). This "transformational class" was in no way interested in areas such as sport. Their main goal was to benefit from the privatization of state-owned enterprises and make quick profit.

\section{The Polish state versus sport}

Not only changes to the industry and its erosion contributed to the regression in sport. It should be noted that the Polish state did not have - let me emphasize - any policy towards sport. It was left alone. One of the interviewees recalls: "they started to introduce ideology that sport has to finance itself, earn money, etc. And all these clubs began to collapse, first of all financially, and then the classic, i.e. they started to profit from this property" (interview 2). We can read about a new path for sport in "Dziennik Bałtycki":

\footnotetext{
Sport is to be decentralized and the main links should be the school and sports club, which is subjected to local government. At the same time, these voluntary talent campuses should be coordinated by a supreme state administration body that distributes funds allocated by the Polish budget. At this moment there is a stumbling block because KKF [the Committee of Physical Culture, and actually the Committee of the Youth and Physical Culture - author's note] would like to leave it as it was (possibly with another change of the authority's name) and the opposition wants to establish institutions composed of completely new people. And so, personal manoeuvring is the background for a structural dispute. [...] As usual, only the press will write about what the renewed Polish sport is to be like. The problem is that journalists are not a driving force (Atlas 1990).
}

At that time, even sport was not an arena for reaching a consensus. In the case of the Forum for the Reform of Culture, the results of its work were questioned by an option related to NSZZ "Solidarność". Representatives of "Solidarność" used votum separatum for fairly general arrangements adopted during the Forum meeting. The assumptions referred to drawing up a draft resolution establishing an institution responsible for physical culture, which would coordinate the government's activities in the field of physical culture, health, leisure, tourism, rehabilitation and environmental protection; defining the principles of an organizational system in professional sport; determining the sources of financing physical culture, creating new legislation in the field of promoting health and physical culture, professional sport and tourism. Representatives of NSZZ "Solidarność" objected to it, relying on the general ideas of self-governance and independence of associations. 
They concluded that the Forum's proposals were against these principles of independence and self-governance. In other words, ideals of self-governance, democratization and decentralizations in dire financial conditions were used as an excuse for a radical retrenchment of state responsibility for financing and maintaining sport clubs and infrastructure. This was compliant with the liberal claim that sport needs to be self-reliant and cope without state aid. It can be said that in 1990 this was a fantasy. "Considering that the first period of transformation, covering the beginning of the 1990s, was characterized by significant recession and a high unemployment rate, connected with rapid privatization of enterprises and liquidation (bankruptcy) of other entities" (Goszczyńska 2010: 205) there was no chance that organizations responsible for promoting physical culture and professional sport could be fully functional.

To illustrate the condition of sport and lack of state policy towards it, I present an appeal that was published in "Dziennik Bałtycki" before the Congress of Physical Culture and Tourism:

Via our newspaper, the organizing committee for the congress would like to ask coastal organizations, activists, coaches and supporters of sport and physical culture to provide in the near future at the address $[\ldots]$ their opinions and conclusions regarding vital issues concerning our sports movement, prospective model solutions for the structures, the system of organizing physical education for children and young people, sport, rehabilitation and tourism, financing rules, etc. (Kowalski 1990).

The Polish state, which was committed to introducing democracy and the free market, had no plans or strategies for organizing sport and physical culture. On the one hand, they were looking for ideas in the grass-roots layers of society immersed in the socialist system, having habits and practices acquired in that system, and on the other one they wanted to detach people from the old era at all costs - which was done by the circles connected with NSZZ "Solidarność", which officially boycotted the Congress. Lack of a specific policy towards sport deepened the regression and collapse of sport. It was not until 18 January 1996 that a posttransformational act regulating physical culture and sport was enacted.

\section{A sports club in uncertain times}

In the years 1990-1992 RKS Stoczniowiec was gradually falling into ruin, like most clubs. Debts were mounting, there was no income. The club's situation was becoming more and more uncertain. Hence, a group of people started to take steps to seize power in the club. Fligstein and McAdam (2012) point out that changes in the institutional field - in this case a sports club - occur when social actors with no power start to struggle to reach their goals. They use their social competences to take power when the existing rules of the game cease to be shared by the people who make up a given organization. They form a coalition based on shared interest. 
Also, in Oliver's concept of deinstitutionalization political factors are stressed as leading to changes in power. They can be described as occurring "when the utility or legitimacy of a practice are called into question" (Dacin, Dacin 2008: 331). Club members questioned the executive board and its strategies of action. They called for a procedure to change the executive board. Such a procedure can be seen in the story of one of the participants taking power in Stoczniowiec:

I said that if we knock things down here, we will make $\mathrm{K}$. the boss, and then $\mathrm{K}$. would make one of us a director and then we will do our job - and continues - K., the former captain of Stoczniowiec Gdańsk, was appointed the chairman. It was an extraordinary general meeting, but I will tell you what to do - with the help of the then director for sport in the voivodeship office, $[\ldots]$ the director who was my friend and supporter - to not let this club be destroyed. I presented the idea, said who supported me, what we could do and that we could destroy this club. But for two years, Stoczniowiec will take over all the debts of Stoczniowiec, because Polonia had debts, the sports hall had debts, J. had debts - debts were everywhere. And we took all the debts and established GKS Stoczniowiec based at ul. Grunwaldzka 470, Hala Olivia and we allocated the Olivia Sports Hall to the club (interview 5).

Taking power over the club was connected with dividing it and taking over the debt. The multi-section club ceased to exist. Individual sections would depart to join new, one-section sports clubs with no debts. The sections that remained in Stoczniowiec were ice hockey, figure skating, volleyball and, for a short time, sports bridge and karate. The remaining sections formed the following clubs: SKS Polonia Gdańsk - football, Szpicgat - canoeing, Drakkar - rowing, MKS Atleta - weightlifting. In 1994, the boxing section finally discontinued its operation, and was taken over by Stocznia Gdańska S.A. The reason for such discontinuation was, among other things, the fact that the Shipyard hall burned down in November 1994. Lack of premises to train and organize boxing matches and the small number of members in the boxing section are the main factors behind the deinstitutionalization of this organization. This example shows how important the organizational dimension was for the club's continued existence; meaning the infrastructure consisting of people and material resources. Lack of one of these factors led directly to operational erosion. However, boxing left a permanent mark, namely payment of health pensions for boxers by RKS Stoczniowiec. Health pensions were granted to them on account of damage to health which they suffered while representing the colours of Stoczniowiec. As one of the interviewees notes:

For example, the boxing section did not exist for 5-6 years and we paid the pensions to boxers, which on the one hand was an item in the budget and on the other, when the plan was to first of all revive the hockey and figure skating section using Olivia, such legacy of the past was an element which firstly cost us money and secondly had no rational justification (interview 4). 
So why was this happening? The interviewee concludes:

They won this, i.e. they won in court, and Stoczniowiec was the successor. There was a club before transformation and after transformation there is a club, too. So there was continuity - it did not matter from a formal or legal point of view that the section was closed (interview 4).

The sports club was still operating. All obligations rested on it. Debts, creditors, debt collectors - all this was the cost which had to be paid for the period of adaptation to the new reality. It should be noted that each of the remaining clubs that "emerged" from RKS Stoczniowiec had its sports facilities. SKS Polonia - a football stadium, MKS Atleta - a sports hall, Drakkar and Szpicgat - marinas, and RKS Stoczniowiec - the Olivia sports hall.

The change of management was vital for the club's future operation. Taking up the position of the chairman by $\mathrm{K}$. had a significant impact on the club's stabilization. When becoming the chairman of Stoczniowiec, K. was a member of the City Board of the city of Gdańsk. This had a considerable impact on the club's fate: "In my time, it certainly helped a lot at the beginning. It needs to be made clear that this support, this communication, ease of access, it helped by all means" (interview 4). We can assume that K. had some social competences that allowed him to initiate cooperation and use various paths to achieve his goals. This is connected with Fligstein and McAdam's concept of social skills, thanks to which a social actor has more competence to act and organize activities (Fligstein 2009; Fligstein, McAdam 2012). In addition, it can be said that these social competences, combined with the social capital (Coleman 1988; Putnam 2008; Grodecki 2018; Burdyka 2019) that he had created within the city of Gdańsk (being a member of the City Board and later of the City Council), created favourable conditions for the strategies implemented to save the sports club, especially as in the first period of transformation in particular nobody wanted to talk and did not talk to local sports clubs. It was not until 1992 that the city of Gdańsk started to support sport. At the beginning, an offer was made to use the facilities of the then Municipal Centre for Sports and Recreation free of charge - which in this case was not important for Stoczniowiec.

An important fact for the club's fate was that the then chairman was at the same time a member of the city board and later on a councillor. Among other things, this made it possible to regulate the legal status of the club and the Olivia hall. One of the interviewees recalls the activities undertaken to regulate the legal status of the facility and the club:

The second stage was to regulate the legal status - in 1993 I made a formal request to regulate the legal status by way of a decision issued by a department in the voivodeship office. The then voivode Płażyński declined his agreement for perpetual usufruct of the premises managed by the club - I appealed against this decision to the Supreme Administrative Court and we won the case. The voivode could not refuse because, according to the documentation, in 1982 we were granted the title to the premises. We did not pay the first instalment for perpetual 
usufruct. In 1983 we received a reminder, in 1984, 1985 and in 1986 the then director called saying that there was no money at that moment and we couldn't pay. On the one hand, as I see it today, it was a gift that this legal status was not regulated - if it had been done, then in 1990 the management would have parcelled it out, sold it, and the Olivia hall would probably not exist today (interview 1).

The facility became the foundation for the club's survival in the difficult times of the transformation. Another interviewee emphasizes this: "In our case, the Olivia hall was the club's enormous wealth" (interview 4). Therefore, regulating the hall's legal status made it possible to manage the facility. Hence, the positions of the chairman of Stoczniowiec seem to be important, because they allowed for not only influencing but also controlling the procedures related to legal regulations. "When there were proposals of resolutions regarding the budget or support, it was possible to lobby, whether it was easier or more difficult to do" (interview 4).

Facility management - generating revenue from facilities for the club - was the first way to earn money. It should be emphasized that at that time the Olivia hall was the only facility in Gdańsk that could accommodate over four thousand spectators. However, the costs generated by the facility were a big problem: electricity, freezing of the ice rink, heating, cleaning, etc. This is illustrated by the words of the person managing the club at that time:

We struggled with two issues - one was a whole set of huge problems related to the facility, because as the manager we were responsible for everything happening at the facility, including its technical condition, security, etc. It was this one administrative aspect, while the other, a parallel one, was an attempt to rebuild this entire sports division, especially the hockey and figure skating section (interview 4).

\section{Sports activity}

The poor financial and organizational situation of Stoczniowiec was felt in the pursuit of its sports activity. The hockey team was not successful, and the players were looking for an additional - or maybe even their only - source of income outside the club. This situation is described by interviewee: "Everyone was looking for some job, because there were no more salaries paid by the club" (interview 3). The club took care of the facility - the ice rink (for both hockey players and figure skaters), equipment and transport to matches (or tournaments). Receiving remuneration either as a salary or as a scholarship was out of the question. As I mentioned, the outflow of players from clubs was significant. This did not create favourable conditions for achievements in sport. In the 1990s, the only success was achieved by juniors, who won the Polish ice hockey championship in 1996. This success translated into the achievements recorded at the beginning of the 21st century, when Stoczniowiec won bronze in the Polish ice hockey championships. However, both these achievements are linked to the change in the economic situation in the coun- 
try. "In the second half of the 1990s economic growth prevailed, remaining at a stable level" (Goszczyńska 2010: 205), which also had a significant impact on sport. This allowed for receiving money from sponsors. This was the case with coaches and players who won the Polish Junior Championships. They received awards from private sponsors (Suska 1996). In addition, the state started to allocate funds to youth sport, which also made the operation of the sports club easier.

\section{Conclusions}

The presented case of RKS (GKS) Stoczniowiec Gdańsk is an example of the process of the reinstitutionalization of a sports organization. Thus, it fits into the survival model - a sports organization undergoes a number of structural, organizational and social changes. Changes in the organization are deep and result from the new institutional (economic and social) order. In other words: the sports club is adapting to the new reality in the institutional field of sport. First of all, the change of the club's structure is important: reducing the number of sections and dividing the club into single-section clubs - was a response to the new times. As one of the interviewees sums up:

Today I think that the club, but also those other clubs, survived because of their division. Drakkar has not regulated its legal status to date and is alive, Atleta is alive, Szpicgat is alive and Polonia is alive. None of these clubs has ceased to exist but they are alive. Stoczniowiec is also alive, and in the meantime it managed to set up two new sections, namely speed skating and curling. A curling sheet has been added - this disintegration, this division of the club, made it possible for these small clubs to survive at a minimum level of course (interview 1).

The club's restructuring was a new solution. Thus, we can conclude that the club managers were looking for new ways to operate, rather than referring to the existing organizational practices. An important element was also the people involved in the club's activities. "I refer to organizational commitment, which defines an employee's sense of connection with the organization, demonstrated primarily by the wish to remain its member and to work for it" (Czarnota-Bojarska 2010: 55). In Stoczniowiec, the involvement of activists and coaches can be linked with their emotional attachment to the club's tradition - some of them were its creators in Communist times, some were players. In some way, emotional attachment was of key importance to the club's fate. If there had been no emotions among the actors, they would not have taken any action for the club. It is only later, in retrospect, that their actions can be considered in the context of rationality, the costs incurred, or profits made. In sport, as Bass notes (2014), emotions play a significant role. In the transformation period, an emotional attitude towards a sports organization also mattered. An example of this could be that taking on the position of the chairperson of a club heading towards bankruptcy (or even one which is bankrupt) is not dictated by a rational calculation. The uncertainty of the existing 
debt primarily gives the sense of uncertainty about the future rather than a sense of stability. Therefore, it can be concluded that the club's tradition and the emotional attachment of individuals to the club are factors that contributed to the activities aimed at keeping the organization alive.

The social capital of the managers played a key role in realizing the club's strategy (Coleman 1988; Putnam 2008; Grodecki 2018; Burdyka 2019). As I have showed above, the chairman of the club used his other position on the City Board and later on the City Council to provide a lobby for sport and also sport organizations. The social capital of his position and the network which he had created was helpful for realizing the survival strategy of "Stoczniowiec".

Another important factor - if not the most important one - was the functional factor. This was related to the material resource which the sports infrastructure constituted. The management of the Olivia hall generated revenue for the club: from the organization of events and renting the facility. Some of the revenues were expended on sports activities and some on facility maintenance. However, bearing in mind that in the first period of transformation there were no other sources of club financing (apart from the proceeds from tickets for hockey matches), such a material resource for generating revenue was a significant factor for the organization's continued existence.

External factors leading to problems in the club's operation are connected with the departure from financing sport through state-owned enterprises (sponsor companies) and the lack of the state policy towards physical culture and sport. Overcoming these factors was a major task for sports activists.

As I have shown above, factors from the Oliver concept illustrate changes in a sports club. In the case of Stoczniowiec, they did not lead to erosion, but under their pressure the organization adapted to the new conditions. In this case, the joint action of social actors to take power over the organization was also visible. The choice of a person with good social skills resulted in a number of changes to save the club from bankruptcy. The theory of fields illustrates the relationships in the institutional field. Relationships, or breaking them, had an impact on activities within the organization and led to the implementation of other strategies than those known from the past.

Returning to the search for answers regarding the opportunities of sports clubs during the transformation, we should remember that no sociological research had previously been carried out on this topic. Within the local space, the conducted survey is the first sociological study of this type focused on sports organizations. Therefore, this innovative study should form the foundation for further research on sports clubs or other types of sports organizations during the political transformation in Poland. 


\section{Bibliography}

Atlas J. (1990), Bicie piany! Przy okragłym stole, "Dziennik Bałtycki”, 25th January.

Bałtowski M., Miszewski M. (2015), Transformacja gospodarcza w Polsce, Wydawnictwo Naukowe PWN, Warszawa.

Bass A. (2014), State of the Field: Sports History and the "Cultural Turn", "The Journal of American History", vol. 101(1), pp. 148-172.

Bogner A., Littig B., Menz W. (eds.) (2009), Interviewing Experts, Palgrave MacMillan, Basingstoke.

Burdyka K. (2019), Między zagrodą a boiskiem. Studium aktywności wiejskich klubów sportowych, Instytut Rozwoju Wsi i Rolnictwa Polskiej Akademii Nauk, Warszawa.

Chołaj H. (1998), Transformacja systemowa w Polsce. Szkice teoretyczne, Wydawnictwo Uniwersytetu Marii Curie-Skłodowskiej, Lublin.

Coleman J.S. (1988), Social Capital in the Creation of Human Capital, "American Journal of Sociology", vol. 94, pp. 95-120.

Czarnota-Bojarska J. (2010), Dopasowanie człowiek-organizacja i tożsamość organizacyjna, Wydawnictwo Naukowe Scholar, Warszawa.

Dacin M.T., Dacin P.A. (2008), Traditions as Institutionalized Practice: Implications for Deinstitutionalization, [in:] R. Greenwood, C. Oliver, T.B. Lawrence, R.E. Meyer (eds.), The SAGE Handbook of Organizational Institutionalism, SAGE Publications, London, pp. 327-351.

Drozdowski R. (2009), Polska - w połowie drogi między pierwszym a drugim skokiem modernizacyjnym, "Ruch Prawniczy, Ekonomiczny i Socjologiczny", vol. LXXI(2), pp. 423-438.

Drozdowski R. (2014), Polska u progu drugiej fazy modernizacji, czyli jak jednocześnie doganiać i uciekać, "Ruch Prawniczy, Ekonomiczny i Socjologiczny", vol. LXXVI(2), pp. 77-88.

Dunn E.C. (2017), Prywatyzując Polskę. O bobofrutach, wielkim biznesie i restrukturyzacji pracy, transl. P. Sadura, Wydawnictwo Krytyki Politycznej, Warszawa.

Federowicz M. (2004), Różnorodność kapitalizmu: instytucjonalizm i doświadczenie zmiany ustrojowej po komunizmie, Wydawnictwo Instytutu Filozofii i Socjologii Polskiej Akademii Nauk, Warszawa.

Fligstein N. (2009), Kompetencje spoleczne i teoria pola, [in:] A. Manterys, J. Mucha (eds.), Nowe perspektywy teorii socjologicznej. Wybór tekstów, Zakład Wydawniczy Nomos, Kraków, pp. 273-300.

Fligstein N., McAdam D. (2012), Theory of Fields, University Press, Oxford.

Gadowska K., Rymsza M. (2017), Od socjologii transformacji do socjologii sfery publicznej. Nowe możliwości syntezy wiedzy o zmianie systemowej, "Studia Socjologiczne", vol. 4(227), pp. 19-47.

Giza-Poleszczuk A., Marody M., Rychard A. (2000), Strategie i system. Polacy w obliczu zmiany społecznej, Wydawnictwo Instytutu Filozofii i Socjologii Polskiej Akademii Nauk, Warszawa.

Goszczyńska M. (2010), Transformacja ekonomiczna w umystach i zachowaniach Polaków, Wydawnictwo Naukowe Scholar, Warszawa.

Graeber D. (2017), Dlug. Pierwsze pięć tysięcy lat, transl. B. Kuźniarz, Wydawnictwo Krytyki Politycznej, Warszawa.

Grodecki M. (2018), Życie po meczu. Formy wykorzystania kapitału społecznego kibiców piłkarskich w Polsce, Wydawnictwa Uniwersytetu Warszawskiego, Warszawa.

Gronkiewicz-Waltz H. (2004), Czynniki transformacji systemu politycznego i gospodarczego bytych państw komunistycznych, "Ruch Prawniczy, Ekonomiczny i Socjologiczny”, vol. LXVI(4), pp. 129-140. 
Jakubowska H., Nosal P. (eds.) (2017), Socjologia sportu, Wydawnictwo Naukowe PWN, Warszawa.

Karpiński A., Paradysz S., Soroka P., Żółtkowski W. (2013), Jak powstawały i jak upadały zakłady przemystowe w Polsce (1946-2012), Muza, Warszawa.

Karpiński A., Paradysz S., Soroka P., Żółtkowski W. (2015), Od uprzemysłowienia w PRL do deindustrializacji kraju. Losy zakładów przemysłowych po 1945 roku, Muza, Warszawa.

Kolasa-Nowak A. (2015), Socjologia historyczna polskich zmian społecznych. Od powstania Solidarności do transformacji systemowej, "Universitatis Mariae Curie-Skłodowska Annales I - Philosophy and Sociology”, vol. XL(2), pp. 19-35.

Kowalik T. (1992), Zmiana ustroju - wielka operacja czy proces społeczny, [in:] R. Gortat (ed.), Społeczeństwo uczestniczące, gospodarka rynkowa, sprawiedliwość społeczna, Uniwersytet Warszawski - Instytut Studiów Politycznych Polskiej Akademii Nauk, Warszawa.

Kowalik T. (2012), From Solidarity to Sellout. The Restoration of Capitalism in Poland, Monthly Review Press, New York.

Kowalski P. (1989), Credo nowego prezesa, "Dziennik Bałtycki”, 8th May.

Kowalski P. (1990), Przed Kongresem Kultury Fizycznej i Turystyki, "Dziennik Bałtycki", 9th July.

Krzemiński I. (ed.) (2011), Wielka transformacja. Zmiany ustroju w Polsce po 1989, Oficyna Wydawnicza Łośgraf, Warszawa.

Lewicki M. (2019), Społeczne życie hipoteki, Wydawnictwo Naukowe Scholar, Warszawa.

Leyk A., Wawrzyniak J. (2020), Cięcia. Mówiona historia transformacji, Wydawnictwo "Krytyki Politycznej”, Warszawa.

Mańkow ski D. (2018), Polski Związek Sportowy jako organizacja w teorii pól Fligsteina i McAdama, "Acta Universitatis Lodziensis. Folia Sociologica", vol. 65. pp. 27-40.

March J.G., Olsen J.P. (2005), Instytucje. Organizacyjne podstawy polityki, transl. D. Sielski, Wydawnictwo Naukowe Scholar, Warszawa.

Marody M. (2011), Państwo a społeczeństwo, [in:] I. Krzemiński (ed.), Wielka transformacja. Zmiany ustroju w Polsce po 1989, Oficyna Wydawnicza Łośgraf, Warszawa, pp. 65-73.

Marody M., Konieczna-Sałamatin J., Sawicka M., Mandes S., Kacprowicz G., Bulkowski K., Bartkowski J. (2019), Społeczeństwo na zakręcie. Zmianyi wartości Polaków w latach 1990-2018, Wydawnictwo Naukowe Scholar, Warszawa.

McSweeney D., Tempest C. (1993), The Political Science of Democratic Transition in Eastern Europe, "Political Studies", vol. XLI, pp. 408-419.

Morawski W. (1998a), Zmiana systemowa jako zmiana instytucjonalna. Uniwersalne wyzwania i polskie adaptacje, [in:] A. Sułek, M.S. Szczepański (eds.), Śląsk-Polska-Europa. Zmieniajace się spoleczeństwo w perspektywie lokalnej, Wydawnictwo Uniwersytetu Śląskiego, Katowice.

Morawski W. (1998b), Zmiana instytucjonalna. Społeczeństwo. Gospodarka. Polityka, Wydawnictwo Naukowe PWN, Warszawa.

Muskat M., Blackman D.A., Muskat B. (2012), Mixed Methods: Combining Expert Interviews, Cross-Impact Analysis and Scenario Development, "The Electronic Journal of Business Research Methods", vol. 10(1), pp. 9-21.

Oliver C. (1992), The Antecedents of Deinstitutionalization, "Organization Studies”, vol. 13(4), pp. $563-588$.

Putnam R.D. (2008), Samotna gra w kręgle: upadek i odrodzenie wspólnot lokalnych w Stanach Zjednoczonych, transl. P. Sadura, S. Szymański, Wydawnictwa Akademickie i Profesjonalne, Warszawa.

Rek-Woźniak M., Woźniak W. (2017), From the Cradle of "Solidarity” to the Land of Cheap Labour and the Home of Precarious. Strategic Discourse on Labour Arrangements in Post-socialist Poland, "Social Policy \& Administration", vol. 51, no. 1, pp. 348-366. 
Staniszkis J. (1994), Dylematy okresu przejściowego. Przypadek Polski, [in:] W. Morawski (ed.), Zmierzch socjalizmu państwowego. Szkice z socjologii ekonomicznej, Państwowe Wydawnictwo Naukowe, Warszawa.

Staniszkis J. (2001), Postkomunizm. Próba opisu, Wydawnictwo słowo/obraz terytoria, Gdańsk.

Stempień J.R. (2020), Dysfunkcjonalizm metodologiczny - nowa propozycja analityczna w socjologii sportu i jej zastosowanie na przykładzie szachów, "Przegląd Socjologii Jakościowej”, vol. XVI, no. 1, pp. 162-185.

Strumińska-Kutra M., Koładkiewicz I. (2012), Studium przypadku, [in:] D. Jemielniak (ed.), Badania jakościowe. Metody i narzędzia, vol. 2, Wydawnictwo Naukowe PWN, Warszawa, pp. $1-40$.

Suska A. (1993), Marek Kostecki-prezes RKS Stoczniowiec. Jeszcze z dlugami, ale już bez komornika, "Dziennik Bałtycki", 10th September.

Suska A. (1996), Hokeiści Stoczniowca kończyli sezon w "Cristalu”. Szpagat pani Joli, "Dziennik Bałtycki”, 17th April.

Yin R.K. (2015), Studium przypadku w badaniach naukowych. Projektowanie i metody, transl. J. Gilewicz, Wydawnictwo Uniwersytetu Jagiellońskiego, Kraków.

Ziółkowski M. (2014), Annus Mirabilis 1989 i jego dziedzictwo: spetnione obietnice, stracone złudzenia i niespodziewane rezultaty, "Ruch Prawniczy, Ekonomiczny i Socjologiczny", vol. LXXVI(2), pp. 25-43.

\title{
SPORT W TRANSFORMACJI USTROJOWEJ W POLSCE GDAŃSKIE STUDIUM PRZYPADKU
}

\begin{abstract}
Abstrakt. Różne obszary życia społecznego i gospodarczego i ich przemian w toku transformacji ustrojowej po 1989 roku były przedmiotem badań i analiz polskich socjologów. Wydaje się, że jednym z obszarów, który pozostał pominięty, stanowi „białą plamę”, jest świat sportu.

Podobnie jak w innych obszarach, indywidualni i zbiorowi aktorzy społeczni, którzy świat sportu organizowali, zarządzali nim lub w nim uczestniczyli, musieli się zmagać z nowym porządkiem społecznym, ekonomicznym i politycznym. Dlatego obraz transformacji ich oczami, a także działania, które podejmowali, motywacje i sposoby radzenia sobie ze zmianami są interesujące i poszerzają wiedzę o okresie przemian.

W artykule prezentuję fragment własnych badań nad przebiegiem i skutkami transformacji ustrojowej na przykładzie wielosekcyjnego Robotniczego Klub Sportowego Stoczniowiec Gdańsk (obecnie GKS Stoczniowiec Gdańsk). Interesują mnie zmagania osób, które organizowały sport, z okresem przemian, a przede wszystkim to, w jaki sposób doświadczały zderzenia z nastającym nowym porządkiem społecznym. Jakie strategie podejmowały w swoich działaniach i praktykach organizacyjnych w czasie transformacji. W rekapitulowanym badaniu studium przypadku jest traktowane jako terenowy i koncepcyjny pilotaż, będący wyjściem do dalszej eksploracji. W studium przypadku korzystałem z dwóch metod: analizy danych zastanych (desk research) (zgromadzono m.in. artykuły prasowe, informacje klubowe, dane urzędowe, dane statystyczne) oraz wywiadów pogłębionych (IDI) z aktorami społecznym działającymi w klubie sportowym. Ramą analityczną dla badania są trzy wymiary transformacji: ekonomiczny, polityczno-prawny oraz społeczny. Natomiast fundamenty teoretyczne to perspektywy nowego instytucjonalizmu, szczególnie teoria pól Fligsteina i McAdama oraz koncepcja deinstytucjonalizacji Christine Oliver.
\end{abstract}

Słowa kluczowe: socjologia sportu, klub sportowy, transformacja, zmiana społeczna, socjologia transformacji. 